\title{
INVESTIGATION OF STRUCTURE AND PROPERTIES OF BIODEGRADABLE COMPOSITIONS OF POLYLACTIDE WITH ETHYL CELLULOSE AND CHITOSAN PLASTICIZED BY POLY(ETHYLENE GLYCOL)
}

\author{
Rogovina Svetlana Zakharovna
}

Doctor of Chemical Sciences, Professor,

Leading Researcher,

N. N. Semenov Institute of Chemical Physics, RAS

s.rogovina@mail.ru

Kosygina St., 4, 119991 Moscow, Russian Federation

\section{Aleksanyan Kristine Vladimirovna}

Candidate of Chemical Sciences,

Researcher of Laboratory of Physical and Chemical Processes in Polymer Systems,

N. N. Semenov Institute of Chemical Physics, RAS

icp@chph.ras.ru

Kosygina St., 4, 119991 Moscow, Russian Federation

\section{Grachev Andrey Vladimirovich}

Engineer,

N. N. Semenov Institute of Chemical Physics, RAS

icp@chph.ras.ru

Kosygina St., 4, 119991 Moscow, Russian Federation

\section{Gorenberg Arkadiy Yakovlevich}

Candidate of Physical and Mathematical Sciences,

Researcher of N. N. Semenov Institute of Chemical Physics, RAS

icp@chph.ras.ru

Kosygina St., 4, 119991 Moscow, Russian Federation

\section{Berlin Aleksandr Aleksandrovich}

Academician of RAS, Doctor of Chemical Sciences,

Director of N. N. Semenov Institute of Chemical Physics, RAS

berlin@chph.ras.ru

Kosygina St., 4, 119991 Moscow, Russian Federation 


\title{
Prut Eduard Veniaminovich
}

Doctor of Chemical Sciences, Professor,

N.N. Semenov Institute of Chemical Physics, RAS

icp@chph.ras.ru

Kosygina St., 4, 119991 Moscow, Russian Federation

\begin{abstract}
Compositions of polylactide (PLA) with polysaccharides ethyl cellulose and chitosan are obtained at different initial ratios of components under conditions of shear deformation in a Brabender mixer. It has been shown that the addition of a given amount of low-molecular poly(ethylene glycol) (PEG) leads to an increase in the elongation of rigid polysaccharide-PLA compositions. The influence of molecular weight and amount of PEG on the thermal behavior of PLA is investigated by DSC method. The biodegradability of films prepared from the blends under investigation is estimated by weight loss after holding in soil and tests on the fungus resistance, and it is shown that the compositions have good biodegradability. The changes in the film morphology after holding in soil revealed by the SEM method additionally confirm that compositions are subjected to biodegradation.
\end{abstract}

Key words: polylactide, chitosan, shear deformation, low-molecular poly(ethylene glycol), biodegradability.

\section{Introduction}

The creation of biodegradable polymer materials for the aim of utilization of synthetic polymer wastes, which can be degraded under the environmental conditions (sunlight, humidity, microorganisms, etc.) with formation of water and carbon dioxide $[2 ; 22 ; 27]$ is one of important problems of modern polymer physics and chemistry.

Among different methods of creation of biodegradable polymer composite materials, the most efficient and economically profitable is the production of polymer materials via mixing synthetic polymers with natural biodegradable ones or mixing natural polymers of different classes. Such polymer compositions allowing one to use the properties of each component can be successfully applied in different areas, especially in production of packaging materials, films for foodstuffs, and articles for short-term application.

There are a lot of works on the production and investigation of biodegradable compositions based on synthetic polymers and natural polysaccharides (see, for example, reviews [2; $27 ; 28]$ ). Under conditions of shear deformation in the absence of solvents, the biodegradable compositions of low density polyethylene with different polysaccharides (starch, cellulose, chitin, ethyl cellulose, chitosan) were obtained and their structure, morphology, and biodegradability were studied. It was shown that the biodegradability depends on the blend composition and the nature of polysaccharide [29-31].

In recent years polylactide (PLA) - a product of lactic acid polymerization - excites a great interest. PLA is isotactic polymer with optical activity of polymers, has L- and Disomers with quite high degree of crystallinity (30-80\%) depending on the production method. PLA density comprises $1.27 \mathrm{~g} / \mathrm{cm}^{3}$, densities of amorphous and crystalline regions are equal to 1.248 and $1.290 \mathrm{~g} / \mathrm{cm}^{3}$, respectively. The glass transition point of PLA lies in the region of 57$60^{\circ} \mathrm{C}$, while the crystallinity degree and melting point depend on the isomer composition. The statistic polymers containing different isomers are less crystalline and soften before melting at lower temperatures.

In comparison with other polyesters based on plant raw material, thanks to complex of thermal and mechanical properties, PLA is most promising for production of plastics and fibers with the given characteristics, especially taking into account serious technological and economic problems at their production, application, and utilization. Due to its high mechanical characteristics, oil and UV radiation stability, the capability of retaining the shape, etc., PLA offers the competition to traditional synthetic polymers. However, the possibilities of its application are 
restricted by low values of elongation at break $(<10 \%)$ and impact strength $\left(\sim 5 \mathrm{~kJ} / \mathrm{m}^{2}\right)$.

The mixing of PLA with synthetic and natural polymers allows one to impart new properties to the materials based on it. This explains the wide range of works dedicated to investigation of blends of PLA with polymers of different classes. For example, the compositions of polylactide with polybutylene carbonate [34], ethylene copolymers [1;10;23], and thermoplastic polyurethanes [11] were studied. The blends based on polylactide and natural rubber are characteristic of a significant increase in the elongation at break compared to PLA [5].

As it is known, pure PLA is biodegradable only under specific conditions (elevated temperature, humidity, etc.) [12;35], unlike its blends with different polymers. The PLA-based compositions with improved biodegradability and high mechanical characteristics were produced with the following polymers: aliphatic polyesters [18; 20], poly([R,S]-3-hydroxybutyrate) [4], poly(3-hydroxybutyrate-co-4-hydroxybutyrate) [13], etc., aliphatic-aromatic copolyesters [15; 16; 19], hyaluronic acid [36], etc.

A lot of works are dedicated to study of the compositions of PLA with chitosan - a biodegradable polymer formed by deacetylation of a nature polysaccharide chitin (for example, $[6 ; 17 ; 38])$. Chitosan is used as a packaging polymer or coating owing to its good film-forming capacity. Among the numerous application areas of the compositions based on chitosan, the medicine is of great importance. The possibility of using chitosan-PLA compositions as a nerve conduit was shown in [38], and this composition was used as a scaffold material in [17]. The compositions with montmorillonite additives, which can be used for the creation of biodegradable devices, which should not be removed from organism, were described in [21].

One of the most widely used plasticizer for PLA is poly(ethylene glycol) $[3 ; 7 ; 8]$. The PLAPEG compositions were studied in detail in $[7$; $14 ; 24 ; 25]$. However, there are no literature data on the influence of different low-molecular PEG on PLA properties.

The aim of this work was the production of biodegradable binary compositions of two polysaccharides - ethyl cellulose and chitosan - with PLA as well as their ternary compositions containing low molecular PEG and investigation of the mechanical characteristics, thermal properties, morphology, and biodegradation capacity. The films prepared from compositions of PLA and chitosan may have the increased water resistance in comparison with the films from pure chitosan that may improve their performance as packaging materials. The compositions based on thermoplastic ethyl cellulose and PLA can be used for molding and casting of the articles for different purposes: spectacle frames, tool handles, toothbrushes, etc.

\section{Experimental Part}

\section{Materials}

Chitosan (deacetylation degree 0.87 and molecular weight $4.4 \times 10^{5}$ (Bioprogress, Russia)), ethyl cellulose (ethoxy group content $46.6 \%$ and dynamic viscosity 57), PLA (density $1.24 \mathrm{~g} / \mathrm{cm}^{3}$, $T_{m}=150-175^{\circ} \mathrm{C}$ (Hycail ${ }^{\circledR}$ HM 1011, Hycail, the Netherlands)), poly(ethylene glycol) of different molecular weight $(600,1000$, and 3000$)$ were used.

\section{Blend production}

Ethyl cellulose and chitosan were blended with PLA in a Brabender mixer (Brabender GmbH \& Co. KG, Dusseldorf, Germany) at $160^{\circ} \mathrm{C}$ for $10 \mathrm{~min}$. The ternary compositions with PEG were obtained in the same apparatus under similar conditions.

\section{Methods of investigation}

\section{Pressing}

For the mechanical tests, the SEM examination, and tests on biodegradability, the films $0.18-0.25 \mathrm{~mm}$ thick were pressed at $160{ }^{\circ} \mathrm{C}$ and $10 \mathrm{MPa}$ for $10 \mathrm{~min}$ followed by cooling under the same pressure at the rate of $15 \mathrm{~K} / \mathrm{min}$. For mechanical tests, the obtained samples were shaped as dumbbell with the size of gauge of $35 \times 5 \mathrm{~mm}^{2}$.

\section{Mechanical tests}

The mechanical tests were performed on an Instron-1122 tensile test machine in tension mode at the rate of the upper traverse of $50 \mathrm{~mm} /$ min at room temperature. Based on the stress $(\sigma)$-strain $(\varepsilon)$ diagrams, the initial elastic modulus $E$, ultimate tensile strength $\sigma_{b}$, and elongation at break $\varepsilon_{b}$ were calculated. The results were averaged for 7-10 samples. 
Thermogravimetric analysis (TGA) and differential scanning calorimetry (DSC)

The thermal stability of individual polymers and their compositions were analyzed on a STA 449 F3 Jupiter synchronic thermal analyzer (NETSCH, Germany) in platinum open pans in the temperature range of $30-560{ }^{\circ} \mathrm{C}$ with the rate of temperature change of $10 \mathrm{~K} / \mathrm{min}$ in air. The sample weight was of $5-8 \mathrm{mg}$, the rate of gas consumption of $10 \mathrm{ml} / \mathrm{min}$.

\section{Investigation of composition biodegradability}

\section{Investigation of biodegradability by weight loss after holding in soil}

The biodegradation of the polymer compositions was studied by holding the samples in soil. The films were placed into a container with wet soil consisting of biohumus, wood ash, finely grinded clay gravel, etc. at $\mathrm{pH}=7.5$. The films were placed into soil on different levels that minimizes the probability of partial loss of films. The containers were kept in a thermostat at $30{ }^{\circ} \mathrm{C}$ for several months. The rate of biodegradation was controlled by the weight losses of samples measured at intervals.

\section{Tests on fungus resistance}

The tests on fungus resistance were performed according to the procedure based on the exposition of the materials infected by fungus spores under the optimum conditions for their growth in aqueous solutions of mineral salts followed by the estimation of fungus resistance by the degree of their growth (State Standard 9.049-91). The samples were shaped as plates $50 \times 50 \mathrm{~mm}$ in size. The concentration of different fungus spores in suspension was $1-2$ billion $/ \mathrm{cm}^{3}$. The test time was 28 days; the fungus resistance in terms of the intensity of fungus growth on the samples was evaluated with a six-number scale.
Scanning electron microscopy

The surface morphology of films prepared from initial binary ethyl cellulose-PLA and chitosan-PLA compositions and from their ternary blends with PEG as well as the film surface morphology after holding in soil were analyzed using a JSM-7001F JEOL scanning electron microscope at accelerating voltages of $1 \mathrm{kV}$, without any treatment of surface.

\section{Results and discussion}

Production of blends and mechanical tests

To endow the biodegradable materials obtained from PLA with new properties and to extend their application areas, the biodegradable polymer compositions - ethyl cellulose-PLA and chitosan-PLA - were produced. The binary compositions of ethyl cellulose and chitosan with PLA containing 30 and 70 wt. \% of polysaccharide (in the case of compositions based on chitosan only 70 wt. \%) were obtained by a solid-phase blending of components under conditions of shear deformation in a Brabender mixer.

The results of mechanical tests of films obtained by pressing of compositions at $160{ }^{\circ} \mathrm{C}$ are given in Tables 1 and 2. As seen from Table 1, the introduction of $30 \mathrm{wt}$. \% ethyl cellulose practically does not change the elastic modulus $(E)$, whereas the addition of $70 \mathrm{wt} . \%$ ethyl cellulose leads to a significant drop of $E$. In the case of chitosan-PLA composition, $E$ slightly increases, since chitosan is more rigid polymer than ethyl cellulose (Table 2 ). The introduction of $70 \mathrm{wt} . \%$ ethyl cellulose leads to a decrease in ultimate tensile strength $\sigma_{b}$ (about 6 times in comparison with pure PLA); the effect observed is probably explained by a poor compatibility of these polymers. For compositions containing $30 \mathrm{wt}$. \% ethyl cellulose or chitosan, this parameter decreased insignificantly compared to

Table 1

Influence of composition of blends based on ethyl cellulose and PLA on mechanical characteristics

\begin{tabular}{|l|c|c|c|c|}
\hline \multicolumn{1}{|c|}{ Composition } & $\begin{array}{c}\text { Blend composition } \\
\text { (wt. \%) }\end{array}$ & $E(\mathrm{MPa})$ & $\sigma_{b}(\mathrm{MPa})$ & $\varepsilon_{b}(\%)$ \\
\hline PLA & - & $2625 \pm 65$ & $52 \pm 1.0$ & $4.7 \pm 0.05$ \\
\hline Ethyl cellulose-PLA & $70: 30$ & $1650 \pm 96$ & $8.7 \pm 0.6$ & $0.9 \pm 0.09$ \\
\hline Ethyl cellulose-PLA & $30: 70$ & $2620 \pm 90$ & $32.7 \pm 1.0$ & $1.9 \pm 0.15$ \\
\hline Ethyl cellulose-PLA-PEG & $30: 60: 10$ & $1500 \pm 74$ & $12.9 \pm 0.4$ & $1.8 \pm 0.13$ \\
& $20: 60: 20$ & $252 \pm 17$ & $4.9 \pm 0.2$ & $20.1 \pm 1.60$ \\
\hline
\end{tabular}


Influence of composition of blends based on chitosan and PLA on mechanical characteristics

\begin{tabular}{|l|c|c|c|c|}
\hline \multicolumn{1}{|c|}{ Composition } & $\begin{array}{c}\text { Blend composition } \\
\text { (wt. \%) }\end{array}$ & $E(\mathrm{MPa})$ & $\sigma_{b}(\mathrm{MPa})$ & $\varepsilon_{b}(\%)$ \\
\hline PLA & - & $2625 \pm 65$ & $52 \pm 1.0$ & $4.7 \pm 0.05$ \\
\hline Chitosan-PLA & $30: 70$ & $3110 \pm 90$ & $45.5 \pm 2.2$ & $2.5 \pm 0.21$ \\
\hline Chitosan-PLA-PEG & $30: 60: 10$ & $1370 \pm 61$ & $17.6 \pm 0.3$ & $3.2 \pm 0.23$ \\
& $20: 60: 20$ & $106 \pm 11$ & $8.9 \pm 0.1$ & $57.5 \pm 2.00$ \\
& $21: 52: 27$ & $181 \pm 28$ & $3.6 \pm 0.05$ & $29.5 \pm 2.20$ \\
\hline
\end{tabular}

PLA. At the same time as is seen from the data of Tables 1 and 2, the addition of ethyl cellulose and chitosan to PLA leads to a substantial decrease of elongation at break $\varepsilon_{b}$. Thus, the change of mechanical characteristics of the polysaccharide blends with PLA depends both on the blend composition and on the polysaccharide nature.

With the aim to increase the elasticity of the films obtained from ethyl cellulose-PLA and chitosanPLA compositions, a plasticizer - PEG $(M=600)$ was added as a third component into the compositions.

The introduction of $10 \mathrm{wt}$. \% PEG leads to a slight change in the elongation at break of blends, while the addition of $20 \mathrm{wt}$ \% PEG results in a significant increase of $\varepsilon_{b}$, especially for compositions containing chitosan. So, the elongation value for ternary chitosan-PLA-PEG (20:60:20 wt. \%) composition increases up to $57.5 \%$ compared to the binary chitosan-PLA composition with the elongation at break of $2.5 \%$ (Table 2). However, further increase in PEG content up to $27 \mathrm{wt}$. \% leads to a decrease of $\varepsilon_{b}$ to $29.5 \%$ that can be connected with the phase separation of the components.

\section{Analysis of blends by DSC and TGA methods}

The thermal behavior of PLA in the presence of PEG of different molecular weight was investigated by DSC method.

Fig. 1 shows the DSC thermograms of PLA and its compositions with $\mathrm{PEG}_{600}$ at different plasticizer contents. Compared to $T_{g}$ of pure PLA $\left(69.3{ }^{\circ} \mathrm{C}\right), T_{g}$ of blends diminishes with increase of $\mathrm{PEG}_{600}$ content up to $44.1^{\circ} \mathrm{C}$ in the presence of 10 wt. \% PEG. The obtained dependence can be explained by a gain in the segmental mobility of PLA with the number of plasticizer molecules leading to the enhancement of PLA molecular mobility. The cold crystallization of both PLA and its blend containing 5 wt. \% $\mathrm{PEG}_{600}$ was not observed, but with increase of PEG content the cold crystallization appears. Moreover, the cold-crystallization temperature $T_{c c}$ of PLA decreases as the PEG content increases, that is connected with a growing number of the crystallization centers. $T_{m}$ of PLA$\mathrm{PEG}_{600}$ blends weakly depends on their composition. The analogous results were obtained for blends of PLA with $\mathrm{PEG}_{1000}$ and $\mathrm{PEG}_{3000}$.

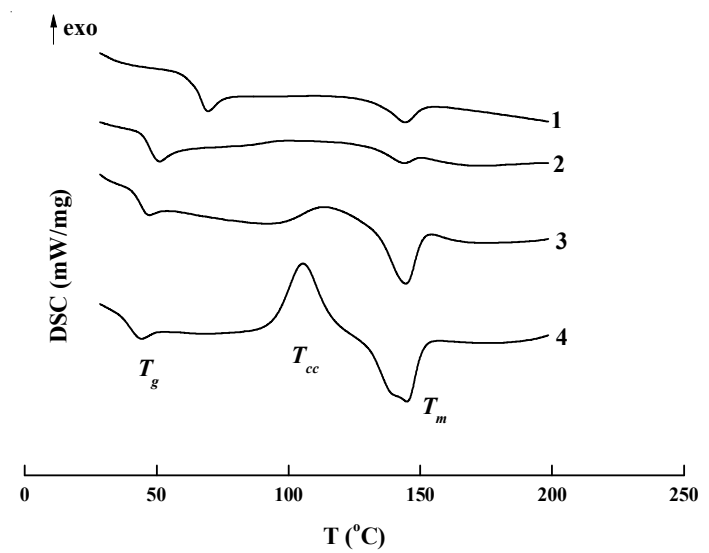

Fig. 1. DSC curves of PLA (1) and PLA-PEG compositions at different component ratio: 95:5 (2),

93:7 (3), and 90:10 wt. \% (4) obtained in air

The determined $T_{g}$ values as well as crystallization and melting temperatures $\left(T_{c c}\right.$ and $\left.T_{m}\right)$ of initial PLA and PLA plasticized by PEGs of different molecular weight $(600,1000$, and 3000$)$ are presented in Table 3. As seen from Table 3, for PEGs of different molecular weights, $T_{g}$ and $T_{c c}$ of PLA-PEG blends decrease with rise of the PEG content. The melting temperature weakly depends on the blend composition, but the heat of melting increases with the rise of content of all PEGs differing in molecular weight that may be explained by increase of the composition crystallinity.

As was found, molecular weight of PEG influences the thermal properties of PLA-PEG blends. Thus, the lower the PEG molecular weight, the stronger decrease of $T_{g}$ of PLA-PEG compositions. This is especially evident when compared PLA-PEG 600 blends with PLA-PEG 1000 and PLA-PEG 3000 blends (Table 3). 
Characteristic temperatures of PLA and PLA-PEG compositions

\begin{tabular}{|l|c|c|c|c|c|}
\hline \multicolumn{1}{|c}{ Composition } & $\begin{array}{c}\text { Blend composition } \\
\text { (wt. \%) }\end{array}$ & $T_{g}\left({ }^{\circ} \mathrm{C}\right)$ & $T_{c c}\left({ }^{\circ} \mathrm{C}\right)$ & $T_{m}\left({ }^{\circ} \mathrm{C}\right)$ & $H_{m}(\mathrm{~J} / g)$ \\
\hline PLA & - & 69.3 & - & 144.4 & 4.5 \\
\hline \multirow{3}{*}{ PLA-PEG 600} & $95: 5$ & 50.7 & - & 144.2 & 1.8 \\
\cline { 2 - 6 } & $93: 7$ & 46.8 & 113.5 & 145.0 & 12.7 \\
\cline { 2 - 6 } & $90: 10$ & 44.1 & 105.4 & 145.5 & 18.6 \\
\cline { 2 - 6 } & $95: 5$ & 52.1 & - & 143.9 & 4.1 \\
\cline { 2 - 6 } & $93: 7$ & 49.3 & 121.5 & 144.8 & 6.4 \\
\hline PLA-PEG $_{1000}$ & $90: 10$ & 46.0 & 105.9 & 145.9 & 21.6 \\
\cline { 2 - 6 } & $95: 5$ & 52.1 & - & 143.6 & 4.7 \\
\cline { 2 - 6 } & $93: 7$ & 49.1 & 120.5 & 144.9 & 11.6 \\
\hline
\end{tabular}

Fig. 2 shows the thermograms of PLA compositions containing 7 wt. \% of PEG of different molecular weight. As seen from Fig. 2, the cold crystallization heats depend on PEG molecular weight and increase with their decrease. This fact can be explained by increase of number of PEG molecules, which are the crystallization centers for PLA, with a decrease of PEG molecular weight. On the other hand, a possibility of interaction of PEG terminal hydroxyl groups with PLA in a Brabender mixer under conditions of shear deformation cannot be excluded. In this case the lower PEG molecular weight is, the greater is the amount of hydroxyl groups capable of reacting with PLA and the higher the heat effect of reaction. The possibility of some chemical reactions in polymers under these conditions was demonstrated in our previous works (see, for example, [26; 32]). However, this problem calls for further investigation.

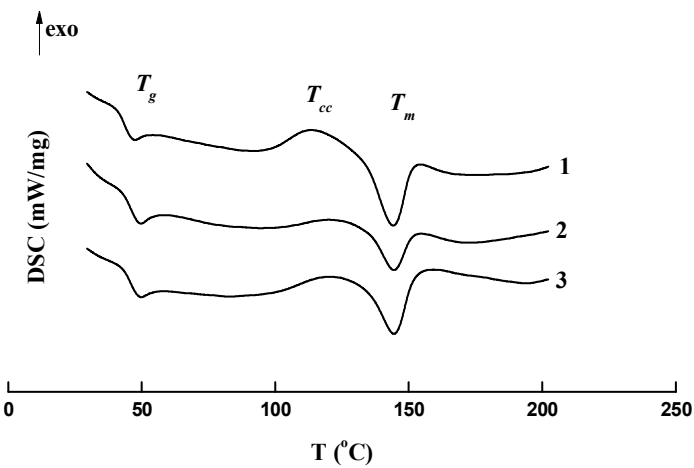

Fig. 2. DSC curves of PLA-PEG ${ }_{600}(1)$, PLA-PEG ${ }_{1000}$ (2), and PLA-PEG ${ }_{3000}(93: 7$ wt. \%) (3) compositions obtained in air

When considering DSC curves of the chitosan-PLA and ethyl cellulose-PLA compositions, the absence of cold crystallization in the curves of the binary compositions of PLA with polysaccharides was found, i.e., the PLA crystallization does not occur in the presence of polysaccharides (Fig. 3, a, curve 1, Fig. 3, b, curve 1). However, the addition of PEG leads to the appearance of a peak of cold crystallization for chitosan-PLA-PEG ${ }_{600}$ and ethyl cellulosePLA-PEG ${ }_{600}$ compositions (Fig. 3, a, curve 2, Fig. 3, $b$, curve 2). At the same time, some decrease in $T_{g}$ for the binary compositions in comparison with the initial PLA is observed (Fig. 3, $a, b$ ).
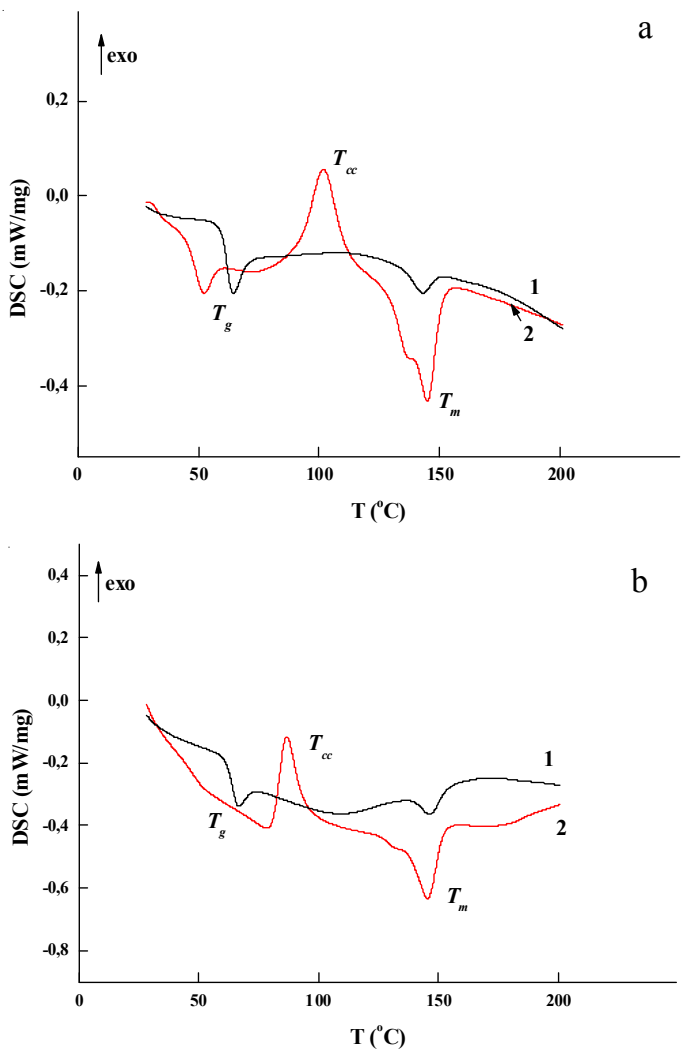

Fig. 3. DSC curves of binary and ternary compositions obtained in air:

$a$ - ethyl cellulose-PLA (30:70 wt. \%) (curve 1) and ethyl cellulose-PLA-PEG ${ }_{600}$ (30:60:10 wt. \%) (curve 2); $b$ - chitosan-PLA (30:70 wt. \%) (curve 1) and chitosanPLA-PEG ${ }_{600}(30: 60: 10$ wt. \%) (curve 2) 
The compositions obtained were also investigated by TGA method. The TG curves of individual chitosan, PLA, PEG $_{600}$, and their binary and ternary compositions are shown in Fig. 4. As can be seen from the presented data, the temperatures of the onset of degradation of binary chitosan-PLA and ternary chitosan-PLA$\mathrm{PEG}_{600}$ (30:60:10 wt. \%) compositions are slightly lower compared to that for pure chitosan.

Thus, the thermal stability of the investigated compositions depends on their composition and the polymer nature. The introduction of PEG into the compositions of polysaccharide with PLA leads to a decrease in the material thermal stability.
Investigation of biodegradability

The biodegradability of obtained compositions was studied by three independent methods.

The tests on biodegradability were performed on the films prepared from the binary ethyl cellulose-PLA and chitosan-PLA (30:70 wt. \%) and ternary ethyl cellulose-PLA-PEG 600 and chitosan-PLA-PEG $600 \quad(20: 60: 20$ wt. \%) compositions.

Investigation of biodegradability by weight loss after holding in soil

The changes occurred in the samples after their holding in soil at $30^{\circ} \mathrm{C}$ for several months were estimated through weight losses. Fig. 5

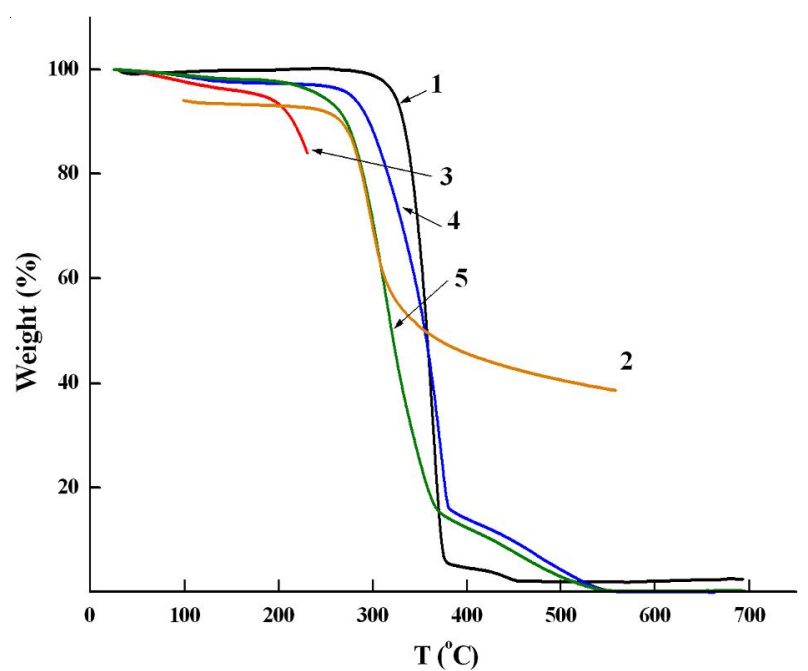

Fig. 4. TG curves of PLA (1), chitosan (2), $\mathrm{PEG}_{600}$ (3), and chitosan-PLA (30: 0 wt. \%) (4), chitosan-PLA-PEG ${ }_{600}(30: 60: 10$ wt. \%) (5) compositions

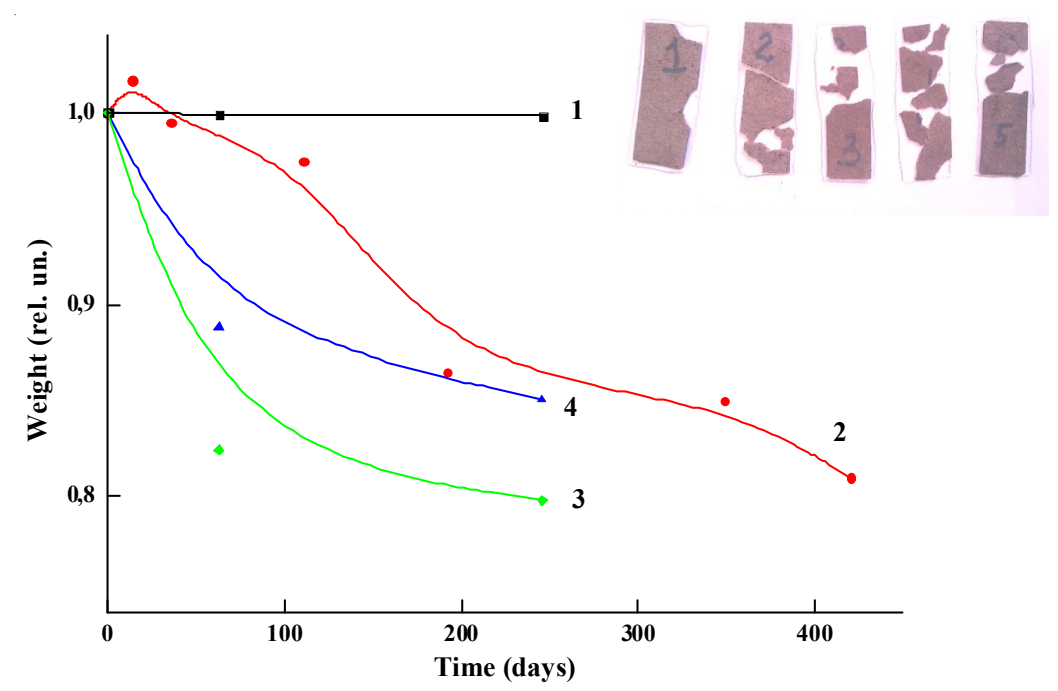

Fig. 5. Weight loss curves of films from ethyl cellulose-PLA (30:70 wt. \%) (1), chitosan-PLA(30:70 wt. \%) (2), ethyl cellulose-PLA-PEG ${ }_{600}\left(20: 60: 20\right.$ wt. \%) (3), and chitosan-PLA-PEG ${ }_{600}(20: 60: 20$ wt. \%) (4) blends after holding in soil for $\sim 12$ months.

Insert: Photographs of films from chitosan-PLA blend (30 : $70 \mathrm{wt}$ \%) after holding in soil 
shows the weight loss curves for the samples held in soil. As seen from Fig. 5, the weight of a binary film containing ethyl cellulose remains almost unchanged throughout the entire experiment, while the binary films containing chitosan and ternary films with PEG are subjected to biodegradation with the weight loss up to $20 \mathrm{wt}$. \%. The appearance of microcracks and spots on the film surface can be clearly seen by the naked eye, especially noticeable changes were observed for the samples containing chitosan; moreover, the samples became significantly more fragile after holding in soil for 12 months (see insert in Fig. 5).

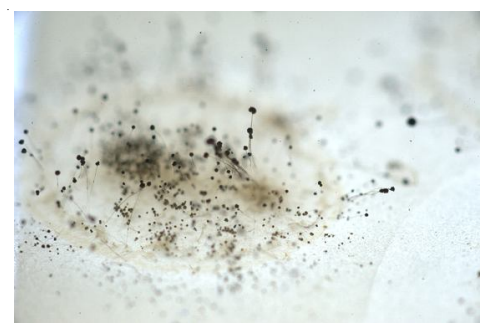

a
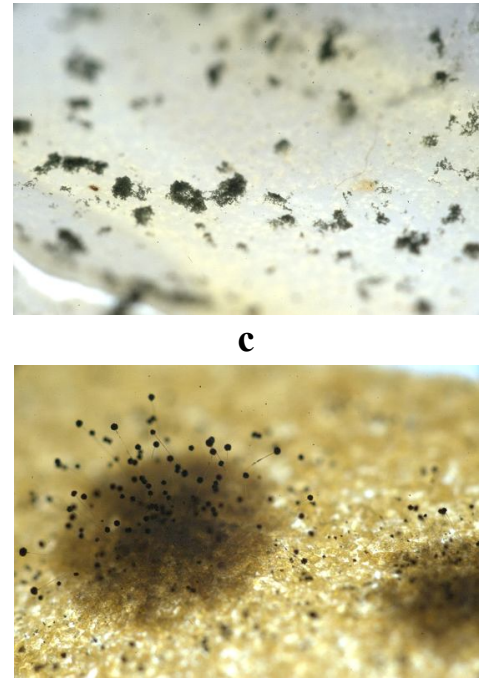

e

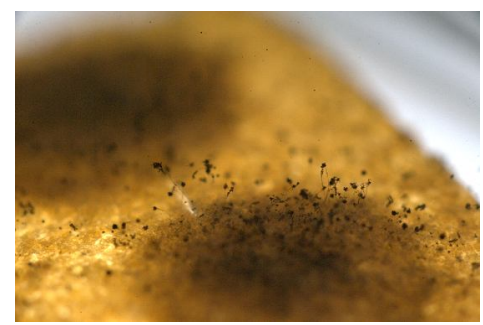

g

\section{Tests on fungus resistance}

The tests on fungus resistance were performed with the films obtained from the investigated binary and ternary compositions (Fig. 6). On examination of films from the compositions containing ethyl cellulose, the materials were not subjected to deep degradation by fungi and the intensity of mold fungus growth was measured according to 2 in the six-number scale. In this case no deep sprouting of the fungus mycelium hyphae inside the film thickness was not observed at magnification $\times 40$ (Fig. 6, $b, d$ ).

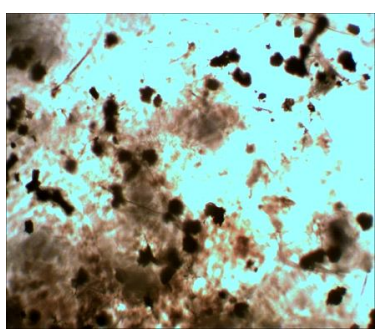

b
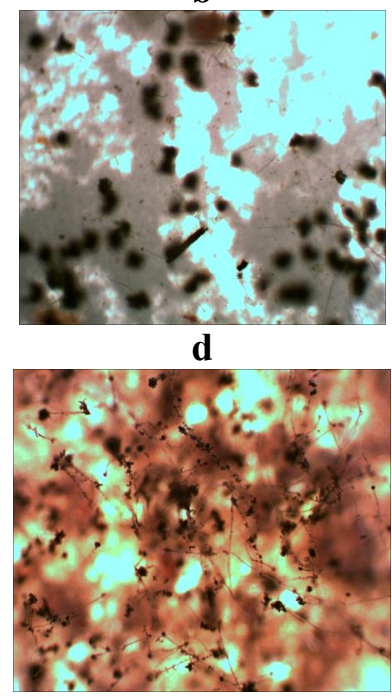

f

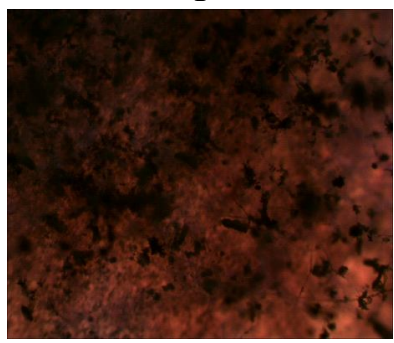

h

Fig. 6. Micrographs of surface of films from ethyl cellulose-PLA (30:70 wt. \%) $(a, b)$, ethyl cellulose-PLA-PEG ${ }_{600}$ $(20: 60: 20$ wt. $\%)(c, d)$, chitosan-PLA (30:70 wt. \%) $(e, f)$, and chitosan-PLA-PEG ${ }_{600}(20: 60: 20$ wt. \%) $(g, h)$ infected with fungus spores for 28 days at different magnifications: $15(a, c, e, g), 40(b, d, f, h)$ 


\section{ТЕХНИКО-ТЕХНОЛОГИЧЕСКИЕ ИННОВАЦИИ}

At the same time the films from chitosan-PLA (30:70 wt. \%) composition were subjected to effective degradation by fungi. At the greater magnification, it is clearly seen that the fungus mycelium hyphae sprouted deeply into the film structure (Fig. 6, $f$ ). The intensity of fungus growth was estimated by the maximum value 5 . The most efficient degradation by the mold fungi was noted for the films from ternary compositions of chitosan: the deep sprouting of the fungus mycelium hyphae into the film structure was observed (Fig. 6, h). The fungus growth intensity of these films was also measured by 5 . However, it

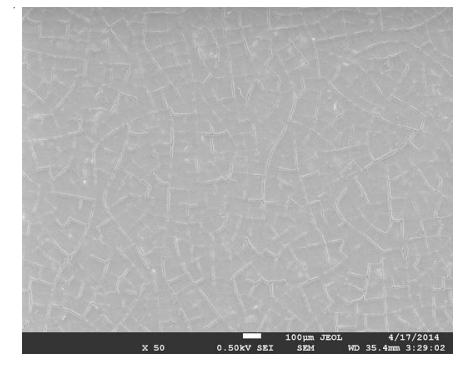

a

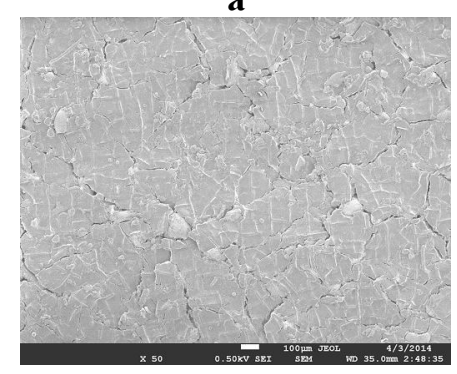

c

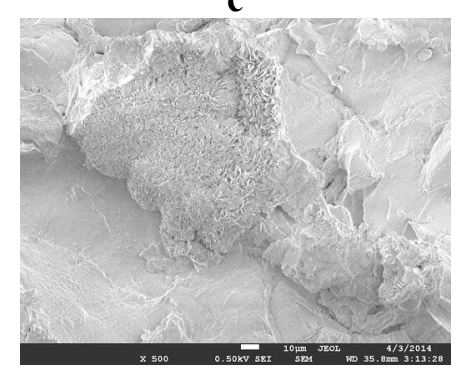

e

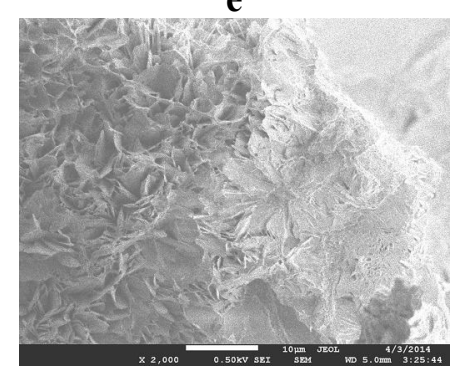

g should be noted that although the fungus growth is clearly seen for all samples by the naked eye, only the compositions containing chitosan showed the maximum biodegradability.

\section{Results of SEM examination of samples after holding in soil}

The surfaces of the films obtained from compositions of PLA with ethyl cellulose and chitosan after holding in soil for several months were investigated by the scanning electron microscopy (SEM) (Figs. 7 and 8). The cross-

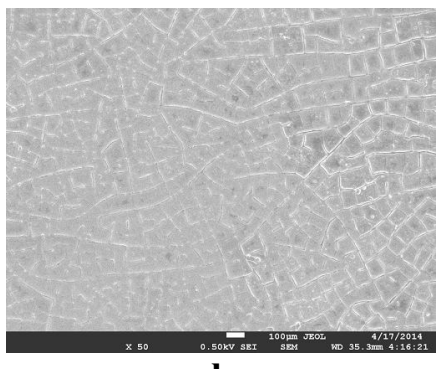

b

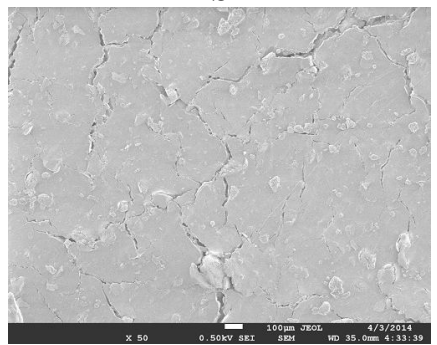

d

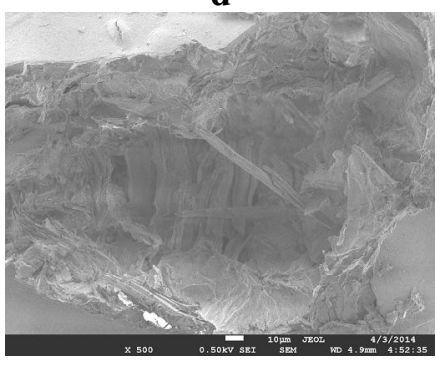

f

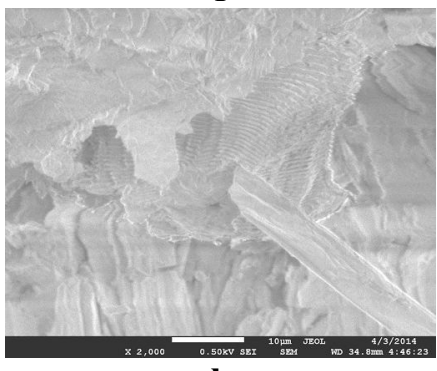

h

Fig. 7. Electron micrographs of surface of films obtained from chitosan-PLA $(a, c, e, g)(30: 70 \mathrm{wt}$ \%) and chitosan-PLA-PEG $(b, d, f, h)(20: 60: 20 \mathrm{wt} . \%)$ blends before $(a, b)$ and after $(c, d, e, f, g, h)$ holding in soil at different magnifications: $50(a-d), 500(e, f), 2000(g, h)$ 


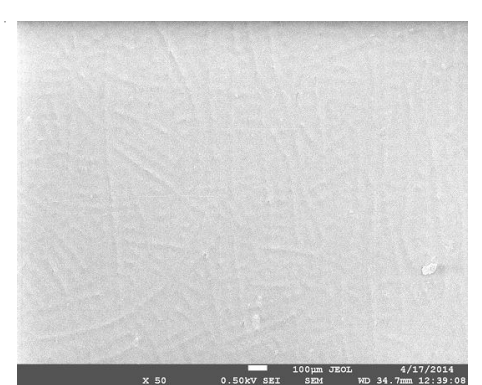

$\mathbf{a}$

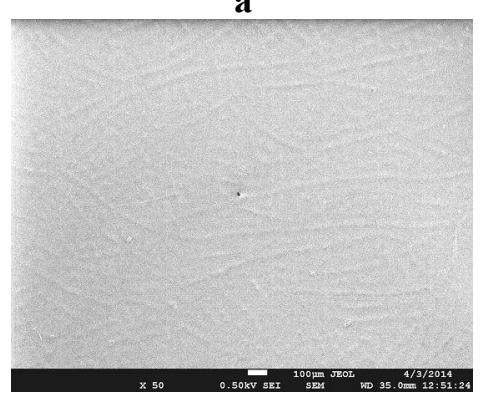

c

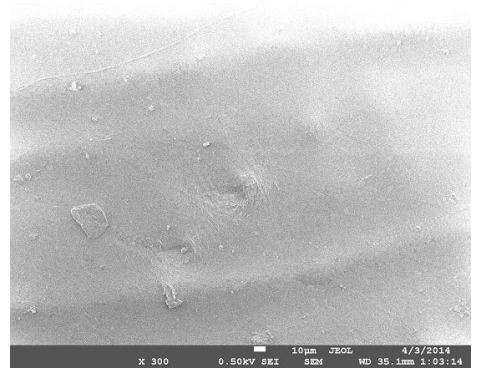

e

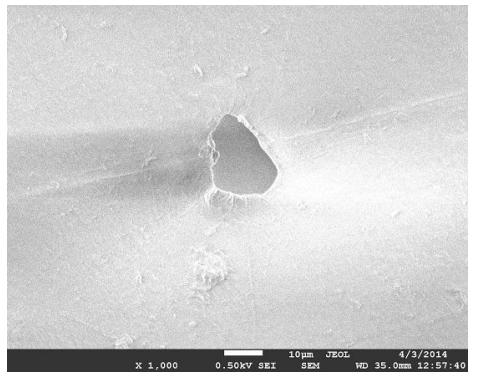

g

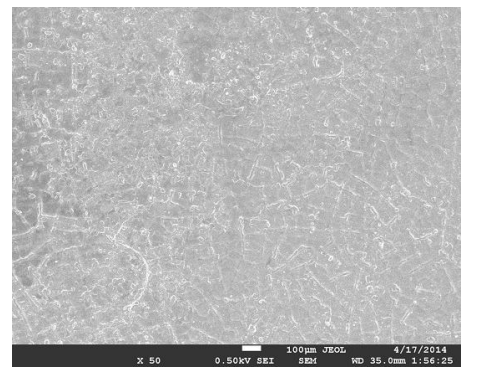

b

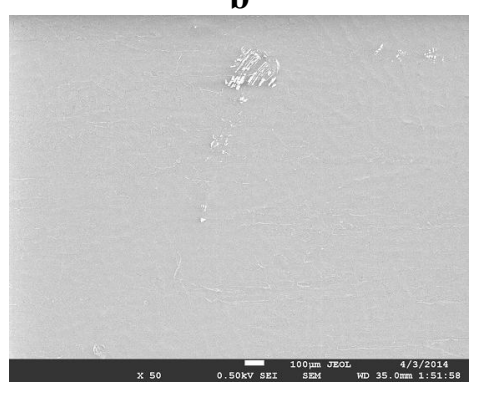

d

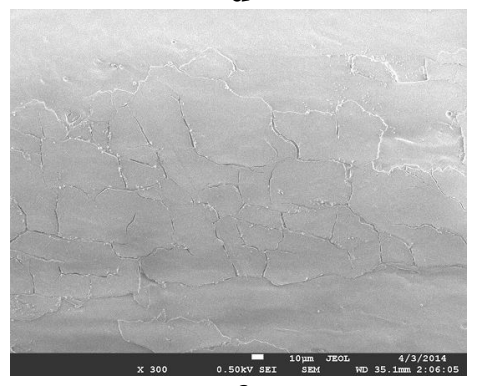

f

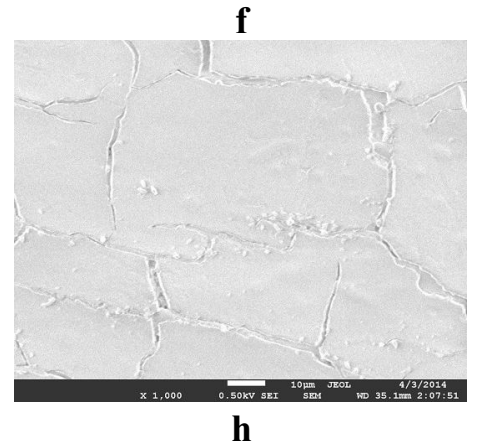

Fig. 8. Electron micrographs of surface of films obtained from ethyl cellulose-PLA ( $a, c, e, g)(30: 70 \mathrm{wt}$ \%) and ethyl cellulose-PLA-PEG $(b, d, f, h)(20: 60: 20$ wt. \%) blends before $(a, b)$ and after $(c, d, e, f, g, h)$ holding in soil at different magnifications: $50(a-d), 300(e, f), 1000(g, h)$

sections of films cannot be investigated, since the samples after holding in soil have an increased fragility.

As seen from micrographs of chitosanPLA film surface after holding in soil, in contrast to the initial compositions, at a low $(\times 50)$ magnification, a network of microcracks that apparently leads to further cracking and fragmentation of the material was observed. At the same magnification, for chitosan-PLA$\mathrm{PEG}_{600}$ compositions, the microcracks are deeper and wider that testifies the more intensive biodegradation of the ternary compositions in the presence of $\mathrm{PEG}_{600}$ in comparison with the binary ones (Fig. 7, $c, d)$. At the medium $(\times 500)$ and high $(\times 2000)$ magnifications (Fig. 7, $e, f)$, the PLA structure as multilayer shell and sponge is clearly seen. At the same magnifications, in the ternary compositions with $\mathrm{PEG}_{600}$, it can be seen that the film structure is more uniform (Fig. 7, $g$, h). The observed cavities in the PLA matrix suggest the presence of biodegradation. 


\section{ТЕХНИКО-ТЕХНОЛОГИЧЕСКИЕ ИННОВАЦИИ}

Different results were obtained for films from the ethyl cellulose-PLA compositions (Fig. 8). At medium $(\times 300)$ magnification, the structure of the PLA matrix containing individual fibrous elements of ethyl cellulose is observed (Fig. 8,e). The addition of $\mathrm{PEG}_{600}$ into composition leads to the appearance of microcracks similar to those observed for chitosan-PLA binary blends, i.e., the biodegradability of the compositions based on ethyl cellulose in comparison with chitosan compositions is pronounced in the presence of $\mathrm{PEG}_{600}($ Fig. $8, f)$. At high $(\times 1000)$ magnification, a cavity, which is apparently formed as a result of PLA biodegradation, is clearly seen (Fig. $8, g, h$ ). Hence, the process of biodegradation occurs not only as a result of polysaccharide degradation, but also is connected with the biodegradation of PLA.

Thus, the SEM data show the differences in morphology of the films containing chitosan or ethyl cellulose after their holding in soil, so it can be concluded that the mechanism and, consequently, the rate of biodegradation are connected with the nature of the polysaccharides used. These data confirm the results obtained on studying the composition resistance to fungus action.

\section{Conclusions}

The biodegradable compositions based on PLA and polysaccharides chitosan and ethyl cellulose were obtained under conditions of shear deformation in a Brabender mixer. The mechanical characteristics of the compositions were determined and it was found that the addition of 20 wt. $\%$ of $P_{E G}$ po0 plasticizer leads to a 20 -fold increase in $\varepsilon_{b}$ values. However, further increase in the PEG content up to $27 \mathrm{wt}$. \% leads to a decrease of $\varepsilon_{b}$ that can be connected with the phase separation of the components.

Using DSC method it was revealed that the introduction of PEG leads to an increase of the PLA macromolecule mobility resulting in a change of $T_{g}$ and $T_{c c}$ depending on the amount and molecular weight of PEG used. The study of biodegradability by tests on fungus resistance showed that the compositions containing chitosan have improved biodegradability compared to the blends based on ethyl cellulose. Using SEM method for investigation of the sample morphology after their holding in soil, it was found that the defects are formed both in the PLA matrix and in polysaccharides that proved the biodegradation of both components.

\section{Acknowledgments}

This work was supported by the Russian Foundation for Basic Research, project No. 1303-12070-ofi_m. This work was produced using equipment of MIPT Center of Collective Use (CCU) with the financial support from the Ministry of Education and Science of the Russian Federation. We are grateful to Yu.I. Deryabina (Bach Institute of Biochemistry) for the help in microbiological experiments.

\section{REFERENCES}

1. Anderson K.S., Lim S.H., Hillmyer M.A. Toughening of Polylactide by Melt Blending With Linear Low-Density Polyethylene. J. Appl. Polym. Sci., 2003, vol. 89, no. 14 , p. 3757.

2. Arvanitoyannis I.S. Totally and Partially Biodegradable Polymer Blends Based on Natural and Synthetic Macromolecules: Preparation, Physical Properties, and Potential as Food Packaging Materials. J. Macromol. Sci., Part C: Polym. Rev., 1999, vol. 39, no. 2, p. 205.

3. Baiardo M., Frisoni G., Scandola M., Rimelen M.,LipsD., Ruffieux K., WintermantelE. Thermal and Mechanical Properties of Plasticized Poly(L-Lactic Acid). J. Appl. Polym. Sci., 2003, vol. 90, no. 7, p. 1731.

4. Bartczak Z., Galeski A., Kowalczuk M., Sobota M., Malinowski R. Tough Blends of Poly(lactide) and Amorphous Poly([R,S]-3-Hydroxy Butyrate) - Morphology and Properties. Eur. Polym. J., 2013, vol. 49, no. 11, p. 3630.

5. Bitinis N., Verdejo R., Cassagnau P., LopezManchado M.A. Structure and Properties of Polylactide/Natural Rubber Blends. Mater. Chem. Phys., 2011, vol. 129, no. 3, p. 823.

6. Bonilla J., Fortunati E., Vargas M., Chiralt A., Kenny J.M. Effects of Chitosan on the Physicochemical and Antimicrobial Properties of PLA. J. Food Eng., 2013, vol. 119, no. 2, p. 236.

7.Chieng B.W., Ibrahim N.A., Yunus W.M.Z.W., Hussein M.Z. Plasticized Poly(Lactic Acid) With Low Molecular Weight Poly(Ethylene Glycol): Mechanical, Thermal, and Morphology Properties. J. Appl. Polym. Sci., 2013, vol. 130, no. 6, p. 4576.

8. Cuenoud M., Bourban P.-E., Plummer C.J.G., Manson J.-A.E. Plasticization of Poly-L-Lactide for Tissue Engineering. J. Appl. Polym. Sci., 2011, vol. 121, no. 4, p. 2078. 
9. Feng F., Ye L. Morphologies and Mechanical Properties of Polylactide/Thermoplastic Polyurethane Elastomer Blends. J. Appl. Polym. Sci., 2011, vol. 119, no. 5, p. 2778.

10. Feng Y., Hu Y., Yin J., Zhao G., Jiang W. HighImpact Poly(Lactic Acid) / Poly(Ethylene Octene) Blends Prepared by Reactive Blending. Polym. Eng. Sci., 2013, vol. 53, no. 2, p. 389.

11. Gumus S., Ozkoc G., Aytac A. Plasticized and Unplasticized PLA / Organoclay Nanocomposites: Short- and Long-Term Thermal Properties, Morphology, and Non-Isothermal Crystallization Behavior. J. Appl. Polym. Sci., 2012, vol. 123, no. 5, p. 2837.

12. Gupta A.P., Kumar V. New Emerging Trends in Synthetic Biodegradable Polymers - Polylactide: A Critique. Eur. Polym. J., 2007, vol. 43, no. 10, p. 4053.

13. Han L., Han C., Zhang H., Chen S., Dong L. Morphology and Properties of Biodegradable and Biosourced Polylactide Blends With Poly(3Hydroxybutyrate-co-4-Hydroxybutyrate). Polym. Compos., 2012, vol. 33, no. 6, p. 850.

14. Hu Y., Hu Y.S., Topolkaraev V., Hiltner A., Baer E. Crystallization and Phase Separation in Blends of High Stereoregular Poly(Lactide) With Poly(Ethylene Glycol). Polymer, 2003, vol. 44, no. 19, p. 5681 .

15. Jiang L., Wolcott M.P., Zhang J. Study of Biodegradable Polylactide/Poly (Butylene Adipate-CoTerephthalate) Blends. Biomacromolecules, 2006, vol. 7 , no. 1, p. 199

16. Jozziasse C.A.P., Topp M.D.C., Veenstra H., Grijpma D.W., Pennings A.J. Supertough Poly(Lactide)s. Polym. Bull., 1994, vol. 33, no. 5, p. 599.

17. Li L., Ding S., Zhou C. Preparation and Degradation of PLA / Chitosan Composite Materials. J. Appl. Polym. Sci., 2004, vol. 91, no. 1, p. 274.

18. Lopez-Rodriguez N., Lopez-Arraiza A., Meaurio E., Sarasua J.R. Crystallization, Morphology, and Mechanical Behavior of Polylactide/Poly(eCaprolactone) Blends. Polym. Eng. Sci., 2006, vol. 46, no. 9 , p. 1299.

19. Ma X., Yu J., Wang N. Compatibility Characterization of Poly(Lactic Acid) / Poly(Propylene Carbonate) Blends. J. Polym. Sci., Part B: Polym. Phys., 2006, vol. 44, no. 1, p. 94.

20. Na Y.-H., He Y., Shuai X., Kikkawa Y., Doi Y., Inoue Y. Compatibilization Effect of Poly(eCaprolactone)-b-Poly(Ethylene Glycol) Block Copolymers and Phase Morphology Analysis in Immiscible Poly(Lactide)/Poly(e-Caprolactone) Blends. Biomacromolecules, 2002, vol. 3, no. 6, p. 1179.

21. Nanda R., Sasmal A., Nayak P.L. Preparation and Characterization of Chitosan-Polylactide Composites Blended With Cloisite 30B for Control Release of the Anticancer Drug Paclitaxel. Carbohydr. Polym., 2011, vol. 83, no. 2, p. 988.
22. Nyambo C., Mohanty A.K., Misra M. Polylactide-Based Renewable Green Composites From Agricultural Residues and Their Hybrids. Biomacromolecules, 2010, vol. 11, no. 6, p. 1654.

23. Oyama H.I. Super-Tough Poly(Lactic Acid) Materials: Reactive Blending With Ethylene Copolymer. Polymer, 2009, vol. 50, no. 3, p. 747.

24. Piorkowska E., Kulinski Z., Galeski A., Masirek R. Plasticization of Semicrystalline Poly(LLactide) With Poly(Propylene Glycol). Polymer, 2006, vol. 47, no. 20, p. 7178.

25. Pluta M. Morphology and Properties of Polylactide Modified by Thermal Treatment, Filling With Layered Silicates And Plasticization. Polymer, 2004, vol. 45, no. 24, p. 8239.

26. Prut E.V., Zelenetskii A.N. Chemical Modification and Blending of Polymers in an Extruder Reactor. Russ. Chem. Rev., 2001, vol. 70, no. 1, p. 65.

27. Rinaudo M. Chitin and Chitosan: Properties and Applications. Prog. Polym. Sci., 2006, vol. 31, no. 7, p. 603.

28. Rinaudo M. Main Properties and Current Application of Some Polysaccharides as Biomaterials. Polym. Int., 2008, vol. 57, no. 3, p. 397.

29. Rogovina S., Aleksanyan K., Prut E., Gorenberg, A. Biodegradable Blends of Cellulose With Synthetic Polymers and Some Other Polysaccharides. Eur. Polym. J., 2013, vol. 49, no. 1, p. 194.

30. Rogovina S.Z., Aleksanyan K.V., Novikov D.D., Prut E.V., Rebrov A.V. Synthesis and Investigation of Polyethylene Blends With Natural Polysaccharides and Their Derivatives. Polym. Sci., Ser. A, 2009, vol. 51, no. 5, p. 554.

31. Rogovina S.Z., Alexanyan Ch.V., Prut E.V. Biodegradable Blends Based on Chitin and Chitosan: Production, Structure, and Properties. J. Appl. Polym. Sci., 2011, vol. 121, no. 3, p. 1850.

32. Rogovina S.Z., Vikhoreva G.A., Akopova T.A., Gorbacheva I.N., Zelenetskii S.N. Reaction of Chitosan With Solid Carbonyl-Containing Compounds Under Shearing Deformation Conditions. Mendeleev Commun., 1998, vol. 8, no. 3, p. 107.

33. Sungsanit K., Kao N., Bhattacharya S.N. Properties of Linear Poly(Lactic Acid)/Polyethylene Glycol Blends. Polym. Eng. Sci., 2012, vol. 52, no. 1, p. 108.

34. Wang X., Zhuang Y., Dong L. Study of Biodegradable Polylactide/Poly(Butylene Carbonate) Blend. J. Appl. Polym. Sci., 2013, vol. 127, no. 1, p. 471.

35. Wu C.-S. Polylactide-Based Renewable Composites From Natural Products Residues by Encapsulated Film Bag: Characterization and Biodegradability. Carbohydr. Polym., 2012, vol. 90, no. 1, p. 583.

36. Wu C.-S., Liao H.-T. A New Biodegradable Blends Prepared From Polylactide And Hyaluronic Acid. Polymer, 2005, vol. 46, no. 23, p. 10017. 
37. Xiao Y., Li D., Chen X., Lu J., Fan H., Zhang X. Preparation and Cytocompatibility of ChitosanModified Polylactide. J. Appl. Polym. Sci., 2008, vol. 110, no. 1, p. 408.
38. XieF., Li Q.F., Gu B., Liu K., Shen G.X. In Vitro and in Vivo Evaluation of a Biodegradable ChitosanPla Composite Peripheral Nerve Guide Conduit Material. Microsurgery, 2008, vol. 28, no. 6, p. 471.

\section{ИССЛЕДОВАНИЕ СТРУКТУРЫ И СВОЙСТВ БИОРАЗЛАГАЕМЫХ КОМПОЗИЦИЙ ИЗ ЭТИЛ-ЦЕЛЛЮЛОЗЫ И ХИТОЗАНА}

\section{Роговина Светлана Захаровна}

Доктор химических наук, профессор, ведущий научный сотрудник, Институт химической физики им. Н. Н. Семенова РАН s.rogovina@mail.ru ул. Косыгина, 4, 119991 г. Москва, Российская Федерация

\section{Алексанян Кристине Владимировна}

Кандидат химических наук,

сотрудник лаборатории физических и химических процессов в полимерных системах, Институт химической физики им. Н. Н. Семенова РАН icp@chph.ras.ru ул. Косыгина, 4, 119991 г. Москва, Российская Федерация

\section{Грачев Андрей Владимирович}

Инженер,

Институт химической физики им. Н. Н. Семенова РАН

icp@chph.ras.ru

ул. Косыгина, 4, 119991 г. Москва, Российская Федерация

\section{Горенберг Аркадий Яковлевич}

Кандидат физико-математических наук,

Институт химической физики им. Н. Н. Семенова РАН

icp@chph.ras.ru

ул. Косыгина, 4, 119991 г. Москва, Российская Федерация

\section{Берлин Александр Александрович}

Доктор химических наук, академик РАН,

директор Института химической физики им. Н. Н. Семенова РАН

berlin@chph.ras.ru

ул. Косыгина, 4, 119991 г. Москва, Российская Федерация 


\section{Прут Эдуард Вениаминович}

Доктор химических наук, профессор, Институт химической физики им. Н. Н. Семенова РАН icp@chph.ras.ru ул. Косыгина, 4, 119991 г. Москва, Российская Федерация

Анотация. Композиции полилактида с полисахаридами этил целлюлозы и хитозана были получены при различных исходных соотношениях компонентов в условиях деформации сдвига в смесителе «Брабендер». Показано, что что композиции имеют хорошую способность к биологическому разложению.

Ключевые слова: полилактид, хитозан, сдвиговые деформации, низкомолекулярный полиэтиленгликоль, способность к биологическому разложению. 